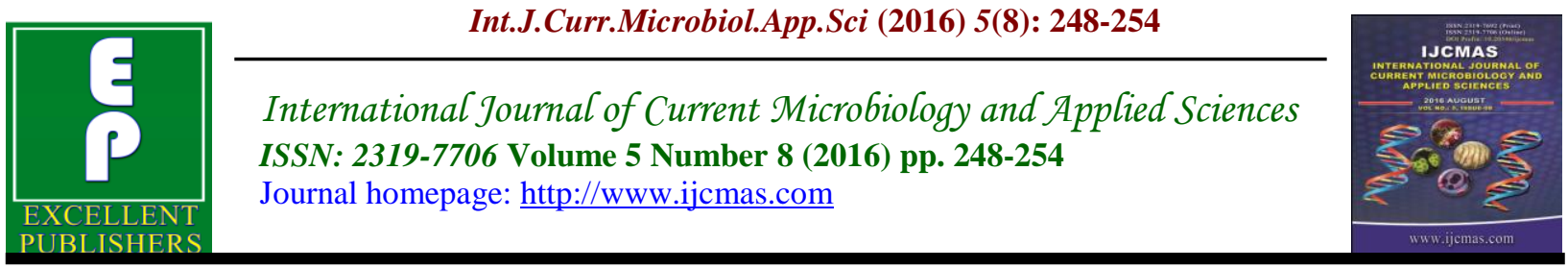

Original Research Article

http://dx.doi.org/10.20546/ijcmas.2016.508.025

\title{
Bacteria Associated with Urinary Tract Infection (UTI)
}

\author{
Neelam Tia ${ }^{1}$ and Moti Lal ${ }^{2}$ \\ ${ }^{1}$ Department of Medicine, Institute of Medical Science BHU, Varanasi, India \\ ${ }^{2}$ School of Biochemical Engineering IIT- BHU Varanasi, India
}

*Corresponding author

\begin{tabular}{|c|c|}
\hline & A B S T R A C T \\
\hline \multicolumn{2}{|l|}{ Keywords } \\
\hline $\begin{array}{l}\text { Bacterial agents, } \\
\text { Urinary Tract } \\
\text { Infection, } \\
\text { Antimicrobial } \\
\text { susceptibility. }\end{array}$ & \multirow{3}{*}{$\begin{array}{l}\text { In the present study, approximately } 300 \text { patients (male and female) have } \\
\text { been taken for observation; with clinical symptoms of UTI will require } \\
\text { antimicrobial treatment. There were } 197(50.7 \%) \text { females and } 103(40.3 \%) \\
\text { males, with an age range of } 28-60 \text { years (mean, } 43.7 \text { years). Escherichia coli } \\
\text { were observed to be the most common cause of UTIs patients. Most } \\
\text { microorganisms occurring in UTIs are found to show maximum sensitivity } \\
\text { against nitrofurantion and minimum sensitivity against norfloxacin. }\end{array}$} \\
\hline Article Info & \\
\hline $\begin{array}{l}\text { Accepted: } \\
\text { 12 July } 2016 \\
\text { Available Online: } \\
10 \text { August } 2016\end{array}$ & \\
\hline
\end{tabular}

\section{Introduction}

Urinary tract infection (UTI) is the second most common infectious presentation in community medical practice. Worldwide, about 150 million people are diagnosed with UTI each year, and UTI are classified as uncomplicated or complicated. A UTI is an infection in the urinary tract. Infections are caused by microbes-organisms too small to be seen without a microscope-including fungi, viruses, and bacteria. Bacteria are the most common cause of UTIs. Normally, bacteria that enter the urinary tract are rapidly removed by the body before they cause symptoms. However, sometimes bacteria overcome the body's natural defenses and cause infection. An infection in the urethra is called urethritis.
A bladder infection is called cystitis. Bacteria may travel up the ureters to multiply and infect the kidneys. A kidney infection is called pyelonephritis (Stamm and Norrby, 2001).

Urinary tract infection (UTI) is an extremely medical problem and about $80 \%$ UTI caused by Escherichia coli. In UTI bacteria that affects any part of the urinary tract. Urinary tract infection is caused by pathogenic invasion of the urinary tract, which leads to an inflammatory response of the urothelium. Since bacteria can enter the urinary tract through urethra (an ascending infection), poor toilet habits can predispose to infection. 
UTIs are most common in sexually active women, increase in diabetic patients and people with sickle cell disease or anatomically malformation of urinary tract; other factors for UTI are an enlarged prostate gland in men, pregnancy in women raising the risk of infection. Patient with indwelling bladder catheter are predisposed to bacteriuria and UTIs. The most common type of UTI is bladder infection which is often called cystitis and another kind of UTI is a kidney infection, known as pyelonephritis, and is much more serious. Infection may be acute or chronic. Although they cause discomfort, UTIs can usually be quickly and easily treated with a short course of antibiotics. Women are more prone to UTIs than men because in females, the urethra is much Shorter and closer to the anus in comparison to males and they lack bacteriostatic properties of prostatic secretion (Hooton 2000). Urinary tract infection may involve only the lower urinary tract or both the upper and the lower tracts. The term cystitis has been used to describe the syndrome involving dysuria, frequency, and occasionally suprapubic tenderness. Acute pyelonephritis describes the clinical syndrome characterized by flank pain or tenderness, or both, and fever, often associated with dysuria, urgency, and frequency (Mandell et al., 2005). More than $95 \%$ of urinary tract infections are caused by a single bacterial species. E. coli is the most frequent infecting microorganism in delicate to the infection (Jellheden et al., 1996, Ronld, 2005). Klebsiella, Staphylococci, Enterobacter, Proteus, Pseudomonas, and Enterococci species are more often isolated from inpatients, whereas there is a greater preponderance of $E$. coli in an outpatient population (Bronsema et al., 1993). Corynebacterium urealyticum has been recognized as an important nosocomial pathogen (Soriano et al., 1990). Anaerobic organisms are rarely pathogens in the urinary tract (Jacob, 1996). Coagulase Negative Staphylococci are a common cause of urinary tract infection in some reports. Staphylococci saprophyticus tends to cause infection in young women of a sexually active age (Schneider and Riley, 1996).

\section{Materials and Methods}

\section{Sampling}

In total, 300 patients with clinical symptoms of UTI referred to Chhatrapati Shahuji Maharaj Medical University (CSMMU) Lucknow were studied. There were 197(50.7\%) females and 103 (40.3\%) males, with an age range of 28-60 years (mean, 43.7 years). Clean-Catch midstream urine of the Patients was collected in a sterile tube (5-10 $\mathrm{ml})$ and immediately transported to the laboratory. Guidelines for proper specimen collection were given to all patients on a printed card (Forbes et al., 2007).

\section{Antimicrobial susceptibility testing}

In the present study antimicrobial susceptibility testing was done on MuellerHinton agar (Merck, Germany) using disk diffusion (Kirby Bauer's) technique. This method was done according to Clinical and Laboratory Standards Institute (CLSI) guidelines to determine susceptibility of UTIs agents (MacFaddin, 2000) Disks diffusion method was used to check antimicrobial activity of tested antibiotics and different disks were loaded with varying concentration of Cefoperazone, Norfloxacin, Nitrofurantion, and gentamicin. Concentration of each antibiotic was kept at $100 \mu \mathrm{g}$ (Foxman, 2002).

\section{Bacterial colony count of bacteria in UTI}

A calculated quantity of urine, using calibrated loop method was inoculated to 
nutrient agar medium (Merck, Germany) for colony count. Equivalent or more than 108 $\mathrm{CFU} / \mathrm{ml}$ of a single potential pathogen or for each of two potential pathogens Interpreted as positive UTI and a result of 100-108 $\mathrm{CFU} / \mathrm{ml}$ was continual. A less than 100 $\mathrm{CFU} / \mathrm{ml}$ was interpreted as negative UTI (Schneider and Riley, 1996) Urine specimens were cultured for isolation of the microbial agents of UTI on blood agar and MacConky agar media. All the bacteria isolated from urine in this study were identified using conventional biochemical tests (Mandell et al., 2005; Forbes et al., 2007; MacFaddin, 2007).

In this present study $46.60 \%$ (in female) sterile urine were found out of 300 patient and $42.77 \%$ in case of male. And total $43.57 \%$ patient urine was found in sterile condition, $5.82 \%$ urine was contaminated in case of female and $14.45 \%$ in male. Candida species was found only in female patient and not in male. $41.74 \%$ urine generally infected by bacteria in male and $38.15 \%$ bacterial infection was found in female urine.

In case of other experiment condition
$27.90 \%$ pyuria have been found in urine of male patient, $24.24 \%$ in Female patient. Finally $25.68 \%$ pyuria found in out of 300 patients.

In this study, $140(48 \%)$ patients out of 300 were showed to be urine culture positive (their colony count was equal or more than 104). There were 197(50.7) females and 103(49.3) males in in patients with urine positive culture gram negative bacilli isolated accounted for 522(94.4\%) of the positive cultures, while Gram-positive cocci were $5.6 \%$. The frequency of isolated microorganisms and their relation to sex is given in table 03. The most common isolated uropathogens in Gram-negative bacilli and Gram-positive cocci were E. coli $(51.37 \%)$ and coagulated negative Staphylococci $(13.63 \%)$ respectively. In this study, the incidence of UTI was ranged in patients between 15-60 (mean, 43.7) years old. The isolated bacterial showed wide differences in their susceptibility to the tested antimicrobial antibiotics. The relation between antimicrobial sensitivity patterns of the isolated bacteria in urine of the population studied is presented in Figure 2.

Table.1

\begin{tabular}{|c|c|c|c|}
\hline Conditions & \multicolumn{3}{|c|}{ No. Isolated (\%) } \\
\hline & Male & Female & Total \\
\hline Pyuria & $27.90 \%$ & $24.24 \%$ & $25.68 \%$ \\
\hline
\end{tabular}

Table.2 Antibiotic sensitivity of Pseudomonas associated with UTI

\begin{tabular}{|l|c|c|c|}
\hline Drugs & $\begin{array}{c}\text { Concentration } \\
(\mu \mathrm{g})\end{array}$ & \multicolumn{2}{|c|}{ Disc diffusion method } \\
\cline { 3 - 4 } & 110 & Sensitive \% & Resistant \% \\
\hline Piperacillin/Tazobactum & 10 & $99.8 \%$ & $0.2 \%$ \\
\hline Norfloxacin & $0.2 \%$ & $99.8 \%$ \\
\hline
\end{tabular}


Fig.1

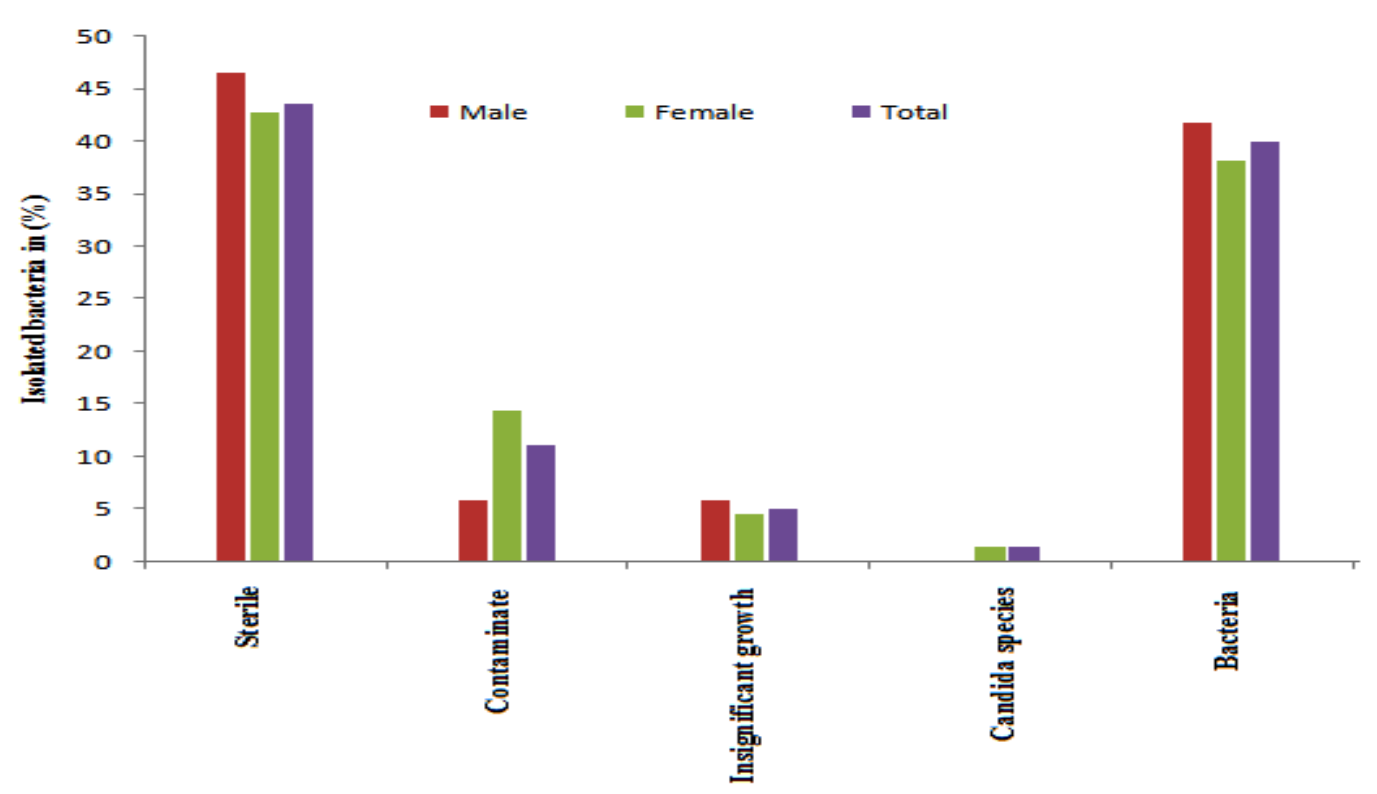

Fig.2 Percentage of different bacteria obtained in urine sample

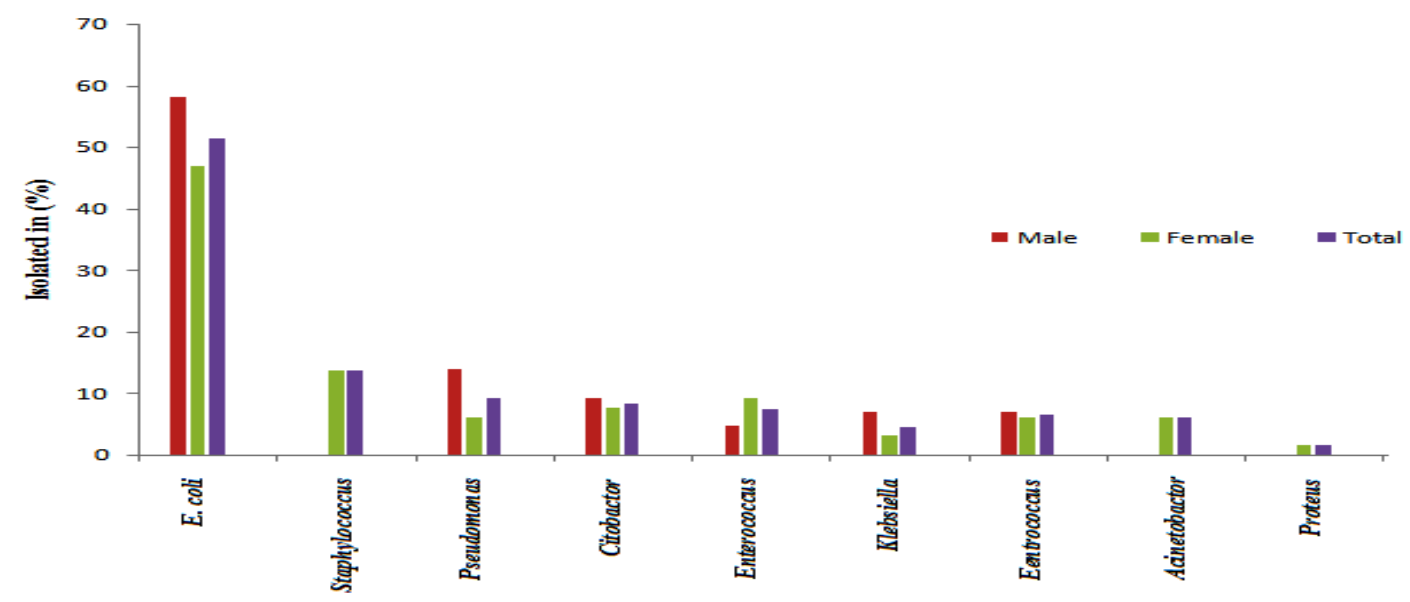

Fig.3 Antibiotic sensitivity of E. coli associated with UTI

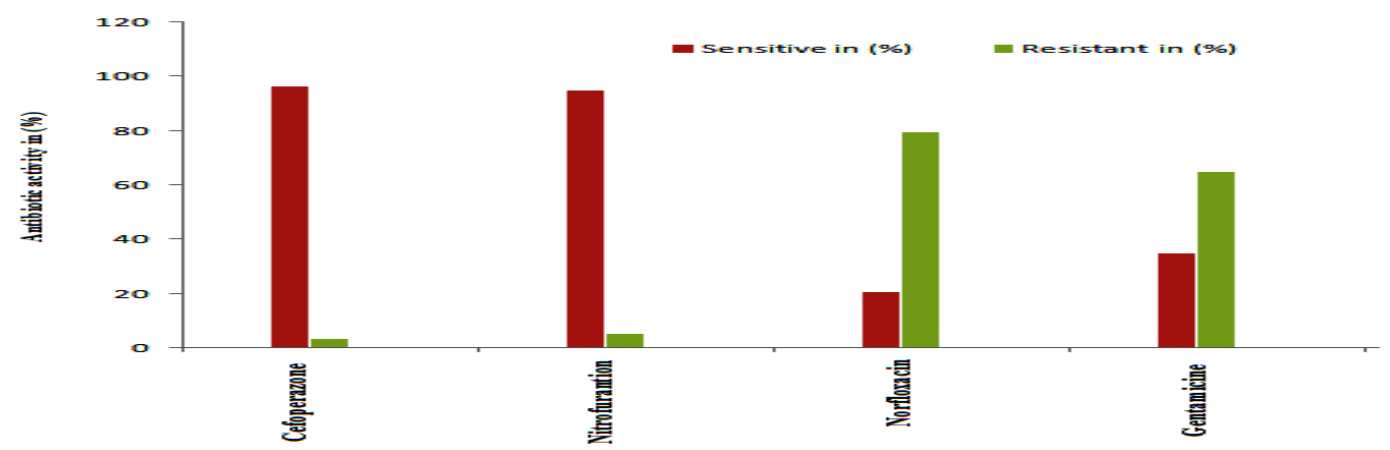


Fig.4 The percentage of UTI on the basis of Age in females and males

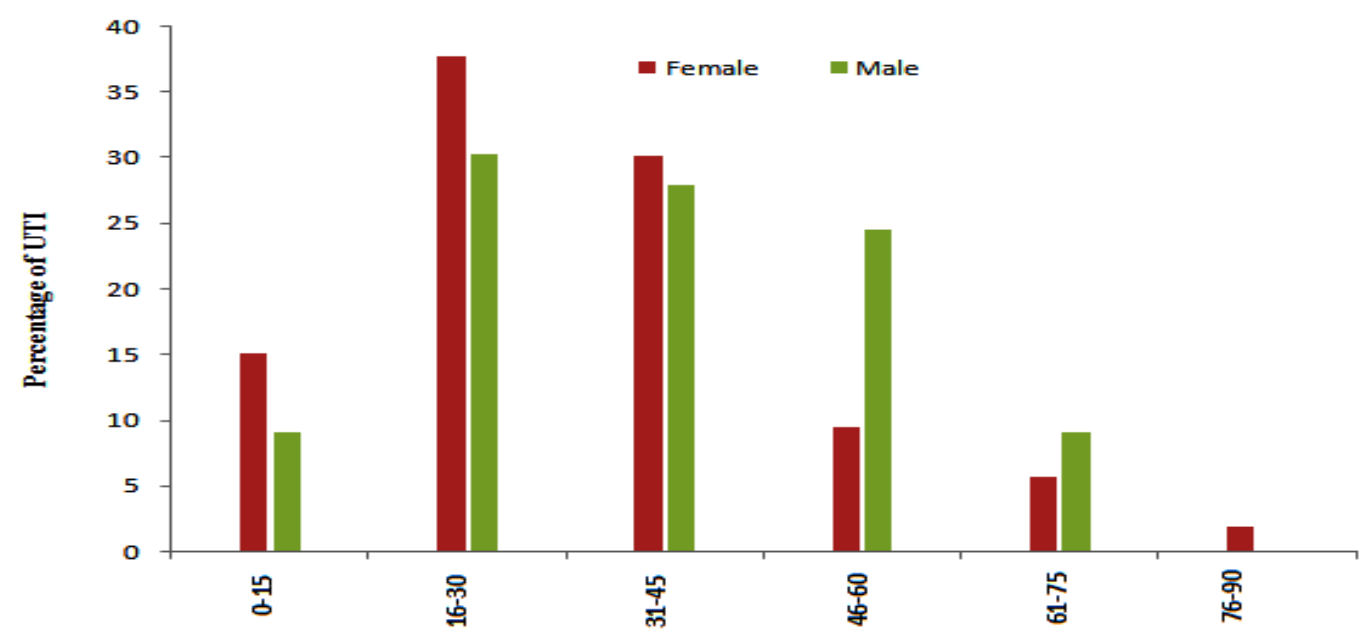

Fig.5 Antibiotic sensitivity of Staphylococcus associated with UTI

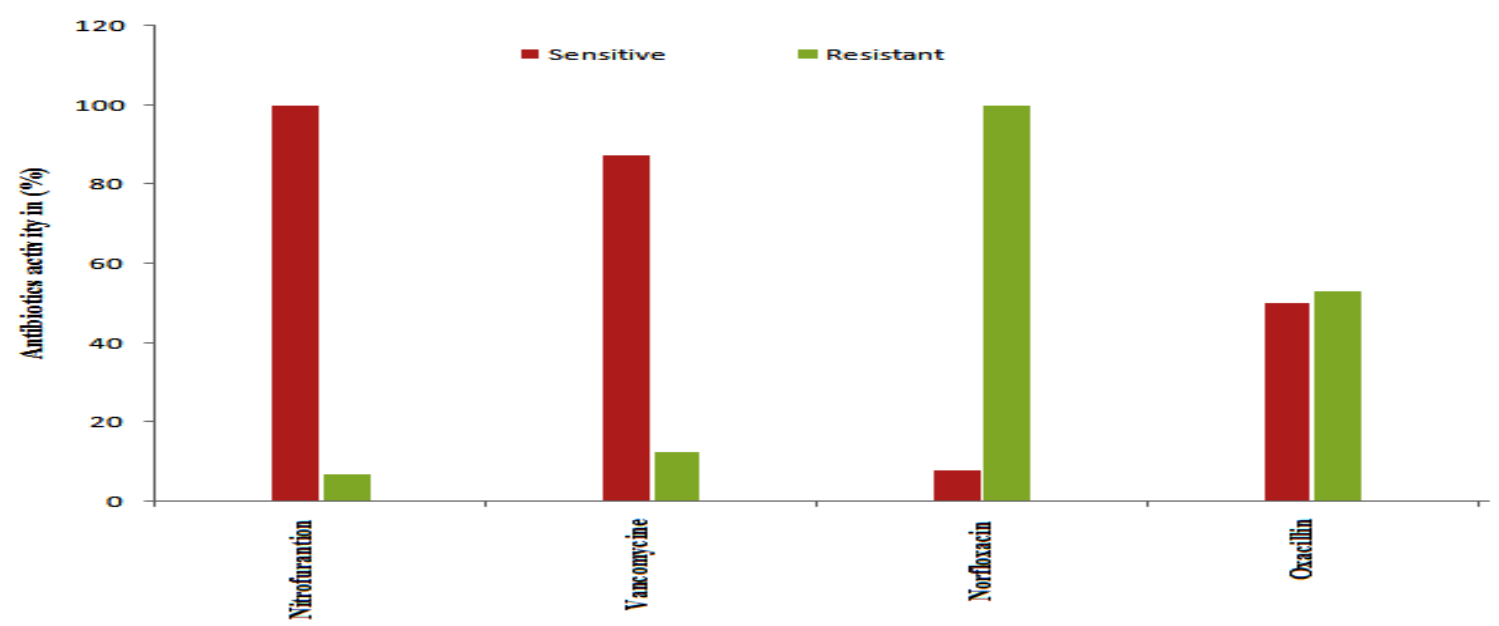

Antibiotic sensitivity of $E$. coli associated with UTI

Based on results obtained from susceptibility testing (Figure 4), all the bacteria recovered from UTI showed the highest degree of resistance to ampicilllin, cephalothin. The Gram-negative bacilli isolated from UTI were sensitive to amikacin and, ciprofleoxacin (83\%- 100\%), and Gram-positive cocci were sensitive to Cefoperazone and Sulbactum (near about 100\%). The Piperacillin was more effective against Pseudomonas spp. And
Acinetobacter spp. isolated in present study. E. coli showed that this bacterium was sensitive to Nitrofurantion, piperacillin, amikacin, (90.5\%).

Most of the isolated bacteria in this study were resistant to norfloxacin (92.8\%), oxacilline (50\%), and vancomycine $(12.5 \%)$. And most of isolate bacteria show the sensitivity agaised to the Nutrofurantion drugs $(99.8 \%)$, vancomycine $(87.5 \%)$, and oxacilline $(50 \%)$. 


\section{Result and Discussion}

On the basis of graph, women between the ages of $15-45$ years have UTI, $(67.91 \%)$ because at this age females are sexually active, most of the females are community acquired (Kothari and Sagar, 2008). The other predisposing factors for UTI in women are diabetes, urethral catherization, pre \& post -menopausal, delay voiding, wiping pattern and having a mother with a history of previous UTI. In men, UTI increases $(57.57 \%)$ between $30-60$ years the percentage of UTI in males in higher and nearer to female's percentage because most of the male patients are hospital acquired (Zhanel et al., 2005).

Although sexual intercourse doesn't seem to be common predisposing factor. Prostatic obstruction and instrumentation become major cause of infection among middle aged and older men. In older population, the role of sexual and contraceptive practice decrease and the other factor may become relatively more important (McIsaac et al., 2004). Urinary tract infections are common conditions worldwide and the pattern of antimicrobial resistance varies in different regions. However, isolated Gram-positive cocci were fully sensitive to Oxacillin, Tazobactum and Norfloxacin. This study is comparable with the results reported by (Astal et al., 2002; McIsaac et al., 2004).

The high prevalence of resistance to the commonly used antibiotics such as ampicilllin, cephalothin and tetracycline has caused considerable alarm (Nurullaev 2004, orrett and Davis, 2006). We describe the relationships between sex, isolated bacterial agents and antibiotic resistance of UTIs. The study was confined to UTIs in adults. In the United States, UTIs account for seven million office visits and 100,000 hospitalizations yearly, making them the most common bacterial infections in outpatient settings.

In conclusion, the higher incidence of UTI in females reflects the shorter urethra and lack of prostate. The increased incidence of UTI in the teens represents urtheral trauma a due to sex ; the general increase with advancing old age reflects obstruction, cystocele etc. Below age 50, UTI is almost entirely a disease of females. The only afflicted male has abnormal anatomy.

\section{Acknowledgement}

The authors would like to thanks Chhatrapati Shahuji Maharaj Medical University (CSMMU) Lucknow for providing necessary facility in this project.

\section{References}

Astal, Z.Y., Sharif, F.A. 2002. Relationship between demographic characteristics and community-acquired urinary tract infection. EMHJ. 8(1): 164-71 Bronsema, D.A., Adams, J.R., Pallares R. 1993. Secular trends in rates and etiology of nosocomial urinary tract infections at a university hospital. $J$. Urol., 150: 414- 6.

Foxman, B. 2002. Epidemiology of urinary tract infections: incidence, morbidity, and economic costs. Am. J. Med., 113(suppl): 5S-13S.

Foxman, B. 2003. Epidemiology of urinary tract infections: incidence, morbidity, and Economic costs. Dis. Mon., 49: 53-70.

Forbes, B.A., Sahm, D.F., Weissfeld, A.S. 2007.Bailey and Scott's Diagnostic microbiology, $12^{\text {th }}$ edition, Mosby Elsevier. 842-55.

Hooton, T.M. 2000. Pathogenesis of urinary tract infections: an update. $J$. Antimicrob. Chemother., 46: 1-7.

Jellheden, B., Norrby, R.S., Sandberg, T. 
1996Symptomatic urinary tract primary health care: Bacteriological, clinical and diagnostic aspects in relation to host Response to infection. Scand J. Prim. Health Care, 14: 122-8.

Jacobs, L.G. 1996Fungal urinary tract infections in the elderly: Treatment guidelines. Drugs $\quad$ Aging, 8: 8996.

Kothari, A., Sagar, V. 2008. Antibiotic resistance in pathogens causing community-acquired urinary tract infections in India: a multi center study. J. Infect. Developing Countries, 2(5): 354-8.

Mandell, G.L., Bennett, J.E., Dolin, R. 2005. Principles and practice of infectious diseases. Churchill Livingstone. 881882.

McIsaac, W.J., Mazzulli, T., Moineddin, R., Raboud, J., Ross, S. 2004. Uropathogen antibiotic resistance in adult women presenting to family physicians with acute uncomplicated cystitis. Can. J. Infect. Dis. Med. Microbiol., 15: 266-70.

MacFaddin, J.F. 2000. Biochemical tests for identification of medical bacteria. 3rd ed. Philadelphia: Lippincott Williams and Wilkins.

McIsaac, W.J., Mazzulli, T., Moineddin ,R., Raboud, J., Ross, S. 2004. Uropathogen Antibiotic resistance in adult women presenting to family physicians with acute uncomplicated cystitis. Can. J. Infect. Dis. Med. Microbiol., 15: 266-70.

Nurullaev, R.B. 2004. The role of Asymptomatic bacteriuria in epidemiologic study the urinar tract infection (UTI). Lik Aprava, 7: 23-5.

Orrett, F.A., Davis, G.K. 1999A comparison of antimicrobial susceptibility profile of urinary pathogensfor the years. West Indian Med, J., 55(2): 95-98.

Ronald, A. 2002. The etiology of urinary tract infection: Traditional and emergin pathogens. Am. J. Med., 113: Suppl 1A: 14S-9S.

Soriano, F., Aguado, J.M., Ponte, C. 1990. Urinary tract infection caused by Corynebacterium group D2: Report of 82 cases and review. Rev. Infect. Dis., 12: 1019-34.

Stamm, W.E., Norrby, S.R. 2001. Urinary tract infections: disease panorama and Challenges. J. Infect. Dis., 183.

Schneider, P.F., Riley, T.V. 1996. Staphylococcus saprophyticus urinary tract infections: Epidemiological data from Western Australia. Eur. J. Epidemiol., 12: 51-4.

Zhanel, G.G. 2005. Antibiotic resistance in outpatient urinary isolates: final results from the NorthAmerican urinary tract infection collaborative alliance (NAUTICA). Int. J. Antimicrob. Agents, 26: 380-8.

\section{How to cite this article:}

Neelam Tia and Moti Lal. 2016. Bacteria Associated with Urinary Tract Infection (UTI). Int.J.Curr.Microbiol.App.Sci. 5(8): 248-254. doi: http://dx.doi.org/10.20546/ijcmas.2016.508.025 